\title{
DO FEMALE ELK SELECT HIDING COVER FOR THEIR CALVES AT BIRTH SITES?
}

\author{
Dillon T. Fogarty ${ }^{1,2}$ and Chadwick P. Lehman ${ }^{1}$
}

\begin{abstract}
In light of local population declines and poor calf survival, we investigated visual obstruction as potential elk (Cervus elaphus) calf hiding cover at birth sites. We hypothesized that female elk would use hiding cover (i.e., visual obstruction) in order to conceal their calves at the birth site and reduce vulnerability to predation. Selection of hiding cover has been well documented at calf bedding sites subsequent to parturition; however, because of variably reported results from prior studies, it is unclear whether hiding cover is selected at the immediate birth site. We estimated visual obstruction of hiding cover, measured understory vegetation height, and categorized the dominant form of hiding cover at 65 birth sites and 116 random sites within the Black Hills, South Dakota. We found no significant differences in visual obstruction, vegetation height, or selection of dominant hiding cover categories between birth and random sites within forest and grassland systems. We surmise that selection of birth sites with greater visibility was used as a strategy to increase detectability of potential human and puma (Puma concolor) disturbances, which may be hindered by understory vegetation or woody debris that obstructs visibility. This may explain why we did not detect any selection for hiding cover; thus, understory cover for calves may not be a driving factor for selection of birth sites.
\end{abstract}

RESUMEN-A la luz del declive de las poblaciones locales y la baja supervivencia de las crías, investigamos la obstrucción visual como potencial protección de las crías, en lugares de nacimiento de ciervo común (Cervus elaphus). Estudiamos la hipótesis de que la hembra del ciervo común usaría una cobertura como protección (es decir, la obstrucción visual) con el fin de ocultar el lugar de nacimiento de sus crías y reducir la vulnerabilidad de las mismas de la depredación. La selección de la cobertura protectora ha sido documentada en los sitios de parto. Sin embargo, debido a la variación reportada en estudios anteriores, no es claro si la cubierta protectora es seleccionada en el sitio de nacimiento inmediato. Estimamos la obstrucción visual como cobertura protectora, midiendo la altura de la vegetación del sotobosque, y clasificamos la forma dominante de la cubierta de 65 sitios de nacimiento y otras 116 zonas seleccionadas al azar dentro de Black Hills, en Dakota de Sur. No encontramos diferencias significativas en la obstrucción visual, altura de la vegetación o selección de las categorías de cobertura protectoras dominantes entre los sitios de nacimiento y las zonas elegidas al azar dentro de los sistemas forestales y de pastizales. Suponemos que la selección de los sitios de nacimiento con mayor visibilidad se utilizó como estrategia para detectar posibles perturbaciones humanas y de pumas (Puma concolor), que ocurrirían en las zonas donde la vegetación del sotobosque o los restos de madera no obstruyen la visibilidad de la hembra de ciervo común. Esto podría explicar por qué no detectamos ninguna selección de cubierta protectora y, por lo tanto, la cobertura de sotobosque utilizada para las crías podría no ser un factor determinante en la selección de los lugares de nacimiento.

Note.-The equivalent of 1 metric ton (t) is $1000 \mathrm{~kg}$ or $1 \mathrm{Mg}$.

North American elk (Cervus elaphus; hereafter elk) exhibit K-selected life history traits, as adult survival rates tend to be high and stable whereas variable calf recruitment rates can affect herd dynamics (Gailliard et al. 1998, 2000). The majority of neonate mortality is caused by predation (Linnell et al. 1995, Smith and Anderson 1996, Singer et al. 1997), and mortality rates are highest during the first weeks of life and decrease as neonates age (Geist 1982, Singer et al. 1997, Barber-Meyer et al. 2008, Lehman 2015). To mitigate predation risk, elk select habitat resources that benefit their antipredator strategies (Lima and Dill 1990, Mysterud and Østbye 1999, Mao et al.
2005). At birth sites and nearby areas, risk of predation to the adult female and neonate may be reduced with habitat selection strategies (adult-Barbknecht et al. 2011, Rearden et al. 2011, Lehman et al. 2016; neonate-Pitman et al. 2014).

Primary factors that contribute to birth site selection by ungulates include human disturbance, forage resources, and predator avoidance (Thomas et al. 1979, Bowyer et al. 1999, Barbknecht et al. 2011, Rearden et al. 2011, Bercovitch and Berry 2015, Lehman et al. 2016). Oftentimes fine-scale selection of birth sites reflects antipredation strategies of the adult (Bowyer et al. 1999, Barten et al. 2001, 
Poole et al. 2007, Barbknecht et al. 2011, Rearden et al. 2011, Smith et al. 2015, Lehman et al. 2016). Antipredation strategies that optimize detection of oncoming threats such as humans or predators can be inversely related to forage abundance. In such cases, moose (Alces alces) cope with these situations by selecting areas that provide more visibility but also the necessary forage to meet nutritional needs (Bowyer et al. 1999, Poole et al. 2007), whereas elk select forage resources at larger scales and increased visibility at smaller scales (Rearden et al. 2011, Lehman et al 2016). Although, elk in Wyoming utilized hiding cover on all scales and, similar to other studies, selected forage at larger scales (Barbknecht et al. 2011). Another factor that can contribute to selection of birth sites is proximity to anthropogenic features such as roads or housing developments. For example, moose in Grand Teton National Park selected birth sites closer to paved roads as risk of predation increased (Berger 2007). Alternatively, bighorn sheep (Ovis canadensis) in the Black Hills selected birth sites that were farther from roads and housing developments to avoid human disturbances (Smith et al. 2015).

Ungulates may select habitat to either optimize visual detection of oncoming threats or increase hiding cover. Both strategies attempt to avoid predation (Lima and Dill 1990, Mysterud and Østbye 1999). During birth and shortly thereafter, any detection of the neonate by a predator drastically increases the risk of predation (Roberts and Rubenstein 2014). Therefore, it is not surprising that during the hiding phase, neonatal young are heavily reliant on hiding cover (Geist 1982, Alldredge et al. 1991, Shallow et al. 2015). Pitman et al. (2014) found that increased cover was important at bedding sites of young elk calves and that adult females selected areas that facilitated the hiding cover needs of the calf. Similarly, Bongi et al. (2008) found that roe deer (Capreolus capreolus) altered their habitat use to provide more cover to neonates. Wallace and Krausman (1990) found that elk calves were usually within a meter of hiding cover and that the type of cover used varied with habitat type. Additionally, Shallow et al. (2015) was able to link concealment cover at mule deer (Odocoileus hemionus) bed sites to increased fawn survival. Given its importance, it is not surprising that hiding cover selection has been widely documented for many species such as white-tailed deer (Odocoileus virginianus; Huegel et al. 1986), mule deer (Gerlach and Vaughan 1991), pronghorn (Antilocapra americana; Canon and Bryant 1997), roe deer (Linnell et al. 1999), and bighorn sheep (Smith et al. 2015).

Our South Dakota study population of elk has been declining since 2006, a trend that is concerning for game managers and hunters (South Dakota Department of Game, Fish and Parks 2015). Our objective was to evaluate resource selection characterizing calf hiding cover at the fine spatial scale at and immediately adjacent to the birth site. Based on previous research that highlights the importance of hiding cover to neonates (Wallace and Krausman 1990, Pitman et al. 2014, Shallow et al. 2015), we hypothesized that to conceal their neonates, female elk would select birth sites with more hiding cover provided by vegetation or woody debris. Further, we hypothesized that even if adult elk desired increased visibility within the $50+$ meters surrounding the birth site they would still be able to select hiding cover immediately adjacent to the birth site.

We conducted our research in Custer and Pennington Counties in southwestern South Dakota in the southern Black Hills physiographic region (Flint 1955). Land ownership was mixed private and public land, including Custer State Park (CSP) which encompassed $286 \mathrm{~km}^{2}$ in the central part of the study area. Elevations ranged from 1108 to $2208 \mathrm{~m}$. Adult female elk were sedated with tranquilizer darts (butorphanol, azaperone, and medetomidine sedation protocol; Mich et al. 2008) deployed from helicopters (QuickSilver Air Inc., Peyton, CO) during February 2012 and 2013. After elk were sedated, we blindfolded and fitted them with satellite radio collars (Telonics Inc., Mesa, AZ.; Advanced Telemetry Systems Inc., Isanti, MN). We aged elk by extracting an upper canine tooth and evaluating cementum annuli (Matson's Lab, Milltown, MT; Hamlin et al. 2000). Female elk were inspected for pregnancy using rectal palpation (Greer and Hawkins 1967, Vore and Schmidt 2001). Females suspected of being pregnant were fitted with a vaginal implant transmitter (Advanced Telemetry Systems, Isanti, MN). Vaginal implant transmitters (VITs) were used to determine locations of birth sites (Barbknecht et al. 2009). A veterinarian was 
on hand to extract teeth, test for pregnancy, and implant transmitters.

We located female elk using radiotelemetry daily from 1 April to 31 October. From 1 November to 31 March, elk were located 5 days per week. Once adult females isolated themselves from others and began to localize, we checked VIT signals twice daily in morning and evening. After birth, expelled VITs were retrieved and their locations were recorded in UTM coordinates with a handheld GPS unit. We collected data from birth sites with substantial evidence of calving. In most cases we observed a calf with the radio-marked cow immediately adjacent to the birth site. Other evidence of the birthing event typically observed near the expelled VIT included placenta material and/or blood at a cleared spot on the ground, as well as a strong odor, moistened soil, and fresh fecal pellets. If VITs were expelled outside the calving season, or if we did not observe evidence of the birthing event, we did not collect data from those sites.

Within a $100 \%$ minimum convex polygon of all female elk locations, we used stratified random sampling (Cochran 1977) to select sites at which to quantify characteristics of the vegetation available to female elk. See Lehman et al. (2016) for detailed methodology on stratified random sampling and vegetation classification. Strata for the random sampling were vegetation structural stages (Buttery and Gillam 1983) described in Lehman et al. (2016). Each year, we randomly selected 5-10 polygons for each stratum of the GIS vegetation coverage without replacement to ensure a comprehensive allocation of random points and sufficient sampling of all the vegetation communities across the study area. We generated one random point in each of these polygons.

We quantified vegetative characteristics at birth sites 3-5 days after the female and calf left the area. We also measured and recorded vegetation characteristics at the random sites during the same period through 31 August each year. We determined understory vegetation characteristics at random points and at birth sites. We estimated percent canopy cover of total herbaceous cover, grasses, forbs, and shrubs in a $0.1-\mathrm{m}^{2}$ quadrat (Daubenmire 1959). We used 4 transects following cardinal directions radiating out from sites and measured percent canopy cover at 2-m intervals $(n=40)$; we averaged data collected along transects for each site. We interpolated downed woody debris (metric tons per hectare $=\mathrm{t} \cdot \mathrm{ha}^{-1}$ ) using a pictorial guide (Simmons 1982). We used a modified Robel pole marked with alternating colors at $2.54-\mathrm{cm}$ increments (Robel et al. 1970, Benkobi et al. 2000) to characterize visual obstruction. This method requires the observer to kneel to a height of $1 \mathrm{~m}$ and record the lowest visible increment on the pole from a distance of $4 \mathrm{~m}$ in each of the cardinal directions $(n=4)$. Visual obstruction measurements were centered at either the birth site or random point and then taken at 5-m intervals in each cardinal direction $(n=4)$. We chose to use $5-\mathrm{m}$ intervals to quantify the visual obstruction that was immediately available to the neonate after birth. We did not include data at the center point of birth or random sites because the birth site often had vegetation removed or disturbed by the cow elk during the birthing event. From each point where visual obstruction readings were taken, we also recorded vegetation height. We classified dominant understory cover at sites using percent canopy cover and woody debris data. When vegetation had $<20 \%$ canopy cover and woody debris was $<17.3 \mathrm{t} \cdot \mathrm{ha}^{-1}$ the site was considered bare. Further, when vegetation canopy cover was $\geq 20 \%$ and/or woody debris was $\geq 17.3 \mathrm{t} \cdot \mathrm{ha}^{-1}$ several dominant cover categories were considered and included: grass/forb, shrub, woody debris, woody debris/grass/forb, and woody/shrub.

We used the multiple-response permutation procedure (MRPP; Mielke and Berry 2001) to test the hypothesis that visual obstruction and vegetation height does not occur randomly across the landscape. MRPP is a distribution test based on Euclidean distance of the hypothesis that the data sets are from the same population. MRPP tests relax the parametric structure requirement of a test statistic and are less affected by an extreme measurement of a single object. We used Pearson chi-square tests to compare dominant cover categories between birth sites and random sites. Significance for all tests was determined at $\alpha=0.05$. All statistical analyses were performed using SPSS Statistics (Version 21, IBM Corporation 2012).

We used birth sites from 36 radio-marked female elk ( $n=35$ adults, $n=1$ yearling) in 
TABLE 1. Visual obstruction readings (VO), vegetation height (VH), and number of sites by cover categories for birth sites and random sites, as well as selection ratios (95\% CIs) for cover categories in the pine forest of the southern Black Hills, South Dakota, 2012-2013.

\begin{tabular}{|c|c|c|c|c|}
\hline \multicolumn{2}{|c|}{$\begin{array}{l}\text { Birth site } \mathrm{VO}=2.78 \mathrm{~cm}(\mathrm{SE} 0.56) \\
\text { Random site } \mathrm{VO}=3.66 \mathrm{~cm}(\mathrm{SE} 0.38)\end{array}$} & \multicolumn{2}{|c|}{$\begin{array}{l}\text { Birth site } \mathrm{VH}=26.44 \mathrm{~cm}(\mathrm{SE} 3.08) \\
\text { Random site } \mathrm{VH}=29.33 \mathrm{~cm}(\mathrm{SE} 2.21)\end{array}$} & \multirow[b]{2}{*}{$95 \% \mathrm{CI}$} \\
\hline Cover category & $\begin{array}{l}\text { Number of } \\
\text { birth sites }\end{array}$ & $\begin{array}{l}\text { Number of } \\
\text { random sites }\end{array}$ & $\begin{array}{l}\text { Selection } \\
\quad \text { ratio }\end{array}$ & \\
\hline Bare $^{\mathrm{a}}$ & 4 & 11 & 1.19 & -0.79 to 3.17 \\
\hline Grass_Forbb & 5 & 32 & 0.53 & -0.09 to 1.14 \\
\hline Shrub $\overline{\mathrm{c}}$ & 0 & 2 & 0 & 0.00 to 0.00 \\
\hline Woody & 4 & 19 & 0.69 & -0.18 to 1.56 \\
\hline Woody_Grass_Forbe & 13 & 28 & 1.52 & 0.43 to 2.62 \\
\hline Woody_Shrubf & 3 & 4 & 2.46 & -2.32 to 7.23 \\
\hline Total & 29 & 96 & - & - \\
\hline
\end{tabular}

aBare ground was $<20 \%$ understory canopy cover of vegetation and $<17.3 \mathrm{t} \cdot \mathrm{ha}^{-1}$ of woody debris

${ }^{b}$ Grass_Forb category was $\geq 20 \%$ grass and forb canopy cover and $<17.3 \mathrm{t} \cdot \mathrm{ha}^{-1}$ of woody debris.

'Shrub category was $\geq 20 \%$ shrub canopy cover and $<17.3 \mathrm{t} \cdot \mathrm{ha}^{-1}$ of woody debris.

dWoody category was $\geq 17.3 \mathrm{t} \cdot \mathrm{ha}^{-1}$ of woody debris and $<20 \%$ canopy cover of vegetation.

eWoody_Grass_Forb category was $\geq 17.3 \mathrm{t} \cdot \mathrm{ha}^{-1}$ of woody debris and $\geq 20 \%$ canopy cover of grasses and forbs

fWoody_Shrub category was $\geq 17.3 \mathrm{t} \cdot \mathrm{ha}^{-1}$ of woody debris and $\geq 20 \%$ canopy cover of shrubs.

TABLE 2. Visual obstruction readings (VO), vegetation height (VH), and number of sites by cover categories for birth sites and random sites, as well as selection ratios (95\% CIs) for cover categories in grasslands of the southern Black Hills, South Dakota, 2012-2013.

\begin{tabular}{|c|c|c|c|c|}
\hline \multicolumn{2}{|c|}{$\begin{array}{l}\text { Birth Site VO = } 3.04 \mathrm{~cm}(\mathrm{SE} 0.37) \\
\text { Random } \mathrm{VO}=2.45 \mathrm{~cm}(\mathrm{SE} 0.33)\end{array}$} & \multicolumn{3}{|c|}{$\begin{array}{l}\text { Birth Site } \mathrm{VH}=34.53 \mathrm{~cm}(\mathrm{SE} 2.52) \\
\text { Random } \mathrm{VH}=26.90 \mathrm{~cm}(\mathrm{SE} 2.93)\end{array}$} \\
\hline Cover category & $\begin{array}{l}\text { Number of } \\
\text { birth sites }\end{array}$ & $\begin{array}{l}\text { Number of } \\
\text { random sites }\end{array}$ & $\begin{array}{l}\text { Selection } \\
\text { ratio }\end{array}$ & $95 \%$ CI \\
\hline Bare $^{\mathrm{a}}$ & 4 & 3 & 0.74 & -0.59 to 2.07 \\
\hline Grass_Forbb & 17 & 8 & 1.18 & 0.20 to 2.16 \\
\hline Shrubc & 1 & 3 & 0.19 & -0.36 to 1.73 \\
\hline Woodyd & 1 & 2 & 0.29 & -0.59 to 1.15 \\
\hline Woody_Grass_Forbe & 13 & 4 & 1.81 & -0.51 to 4.12 \\
\hline Total - - & 36 & 20 & - & - \\
\hline
\end{tabular}

a Bare ground was $<20 \%$ understory canopy cover of vegetation and $<17.3 \mathrm{t} \cdot \mathrm{ha}^{-1}$ of woody debris

bGrass_Forb category was $\geq 20 \%$ grass and forb canopy cover and $<17.3 \mathrm{t} \cdot \mathrm{ha}^{-1}$ of woody debris.

cShrub category was $\geq 20 \%$ shrub canopy cover and $<17.3 \mathrm{t} \cdot \mathrm{ha}^{-1}$ of woody debris.

dWoody category was $\geq 17.3 \mathrm{t} \cdot \mathrm{ha}^{-1}$ of woody debris and $<20 \%$ canopy cover of vegetation.

eWoody_Grass_Forb category was $\geq 17.3 \mathrm{t} \cdot \mathrm{ha}^{-1}$ of woody debris and $\geq 20 \%$ canopy cover of grasses and forbs.

our analyses, resulting in 65 birth sites measured over 2 years. We also collected data from 116 random sites. We evaluated selection separately in pine forests $(n=29$ birth sites, $n=96$ random sites) and grasslands $(n=36$ birth sites, $n=20$ random sites). Visual obstruction did not differ (MRPP test statistic $\leq 0.33$, $P \geq 0.25)$ between birth sites and random sites in forests (Table 1) or grasslands (Table 2). Vegetation height did not differ (MRPP test statistic $\leq 0.95, P \geq 0.13$ ) between birth sites and random sites in forests (Table 1) or grasslands (Table 2). Selection of dominant cover categories did not differ $\left(\chi^{2} \leq 6.68, \mathrm{df}=4\right.$ or $5, P \geq 0.25)$ from random sites, and selection ratios indicated no selection for any categories (Tables 1, 2).
We found no support for our hypothesis that elk select more hiding cover for their neonates at birth sites. On the basis of previous research that highlights the importance of hiding cover, our results were unexpected. Young ungulates, whose only defense is to hide, select areas for themselves with more hiding cover (Gerlach and Vaughan 1991, Canon and Bryant 1997, Linnell et al. 1999), including elk (Wallace and Krausman 1990, Pitman et al. 2014). Given the importance of hiding cover away from the birth site, we predicted that female elk would select hiding cover for their calves at the birth site; however, this selection was not found.

We suspect that adult elk are exposed to high risk at the birth site, and due to the 
hunting tactics of a major predator in our study area, the adult and neonate's predator avoidance strategies were in opposition to each other. Further, we surmise that this conflict resulted in a compromise of neonate hiding cover in order to maximize the security of the adult. Annual survival rates of calves were $\leq 27 \%$ for 3 years of the study, and $26 \%$ of predation mortality occurred within 5 days of birth (Lehman 2015), or during the hiding phase (Geist 1982). Most calf mortality was from puma (Puma concolor) predation (Lehman 2015). To mitigate their own predation risk, adult female elk can select for optimal security cover (Thomas et al. 1979, Lehman et al. 2016), which may vary depending on the hunting tactics of major predators. For instance, coursing predators like grizzly bears (Ursus arctos) and wolves (Canis lupus) prefer hunting in open areas where they can peruse prey at long distances; in contrast, puma prefer dense concealment which allows them to stalk and ambush prey in close quarters (Mech 1970, Beier et al. 1995). Avoidance of areas that favor the hunting strategies of major predators is a common antipredation strategy used by ungulates such as moose (Bowyer et al. 1999), caribou (Rangifer tarandus; Barten et al. 2001), elk (Creel et al. 2005), roe deer (Bongi et al. 2008), and mule deer (Long et al. 2009). In the hiding phase, any detection of the neonate by predators drastically increases the chance of predation (Roberts and Rubenstein 2014); therefore, selection of hiding cover appears to be beneficial to the neonate, regardless of major predators. However, this strategy is in opposition to strategies used to avoid ambush predators like the puma. Both Lehman et al. (2016) and Rearden et al. (2011) studied elk in environments where puma were the primary predator and found selection of birth sites that provided visibility, presumably to allow detection of oncoming humans or puma. In contrast, Barbknecht et al. (2011) studied elk in the Greater Yellowstone Ecosystem with a suite of coursing and ambush predators and found selection for more cover. This study did not identify major predators, although it appears that both adult and neonate predator avoidance strategies may have benefited. Since puma predation and avoidance of humans were significant factors in our study area, we suggest that selection of calf hiding cover would have impeded visual detection of predators by females in an already risky environment. Therefore, understory cover for calves may not be a driving factor for selection of birthing sites in our case study. Future studies could further explore this relationship between calf hiding cover and adult elk resource selection.

Funding for this research was provided by the Rocky Mountain Elk Foundation and the South Dakota Department of Game, Fish and Parks. Field support was provided by J. Kragel, A. Coleman, K. Kaskie, N. Markl, T. Gingery, M. Lenny, G. Lenny, L. Flack, and K. Knudsen. Additional field assistance and technical support was provided by the United States Forest Service Rocky Mountain Research Station. All handling, marking, and monitoring procedures were approved by the South Dakota State University Research Committee (Animal Care and Use Committee Approval Number 11-012A) and followed guidelines for the care and use of animals approved by the American Society of Mammalogists (Sikes et al. 2011).

\section{Literature Cited}

Alldredge, A.W., R.D. Deblinger, And J. Peterson. 1991. Birth and fawn bed site selection by pronghorns in a sagebrush-steppe community. Journal of Wildlife Management 55:222-227.

Barber-Meyer, S.M., L.D. Mech, And P.J. White. 2008. Elk calf survival and mortality following wolf restoration to Yellowstone National Park. Wildlife Monographs 169:1-30.

Barbknecht, A.E., W.S. Fairbanks, J.D. Rogerson, E.J. Maichakm, B.M. Scurlock, And L.L. Meadows. 2011. Elk parturition site selection at local and landscape scales. Journal of Wildlife Management 75: 646-654.

Barbknecht, A.E., J.D. Rogerson, E.J. Maichak, W.S. Fairbanks, And L.L. MEadows. 2009. Effectiveness of vaginal implant transmitters for locating elk parturition sites. Journal of Wildlife Management 73: 144-148.

Barten, N.L., R.T. Bowyer, And K.J. Jenkins. 2001. Habitat use by female caribou: tradeoffs associated with parturition. Journal of Wildlife Management 65:77-92.

Beier, P., D. Choate, And R.H. Barrett. 1995. Movement patterns of mountain lions during different behaviors. Journal of Mammalogy 76:1056-1070.

Benkobi, L., D.W. Uresk, G. Schenbeck, and R.M. KING. 2000. Protocol for monitoring standing crop in grasslands using visual obstruction. Journal of Range Management 53:627-633.

Bercovitch, F.B., AND P.S.M. Berry. 2015. Giraffe birth locations in the south Luangwa National Park, Zambia: site fidelity or microhabitat selection? African Journal of Ecology 53:206-213. 
Berger, J. 2007. Fear, human shields and the redistribution of prey and predators in protected areas. Biology Letters 3:620-623.

Bongi, P., S. Ciuti, S. Grignolio, M. Del Frate, S. Simi, D. Gandelli, and M. Apollonio. 2008. Anti-predator behaviour, space use and habitat selection in female roe deer during the fawning season in a wolf area. Journal of Zoology 276:242-251.

Bowyer, R.T., V. Van Ballenberghe, J.G. Kie, and J.A.K. MAIER. 1999. Birth-site selection by Alaskan moose: maternal strategies for coping with a risky environment. Journal of Mammalogy 80:1070-1083.

Buttery, R.F., and B.C. Gillam. 1983. Forested ecosystems. Pages 43-71 in R.L. Hoover and D.L. Wills, editors, Managing forested lands for wildlife. Colorado Division of Wildlife and U.S. Forest Service, Rocky Mountain Region, Denver, CO.

CanON, S.K., AND F.C. BRYANT. 1997. Bed-site characteristics of pronghorn fawns. Journal of Wildlife Management 61:1134-1141.

Cochran, W.G. 1977. Sampling techniques. 3rd edition, John Wiley \& Sons, Inc., New York, NY.

Creel, S., J. Winnie Jr., B. MaXwell, K. Hamlin, and M. CREEL. 2005. Elk alter habitat selection as an antipredator response to wolves. Ecology 86:3387-3397.

Daubenmire, R. 1959. A canopy-coverage method of vegetational analysis. Northwest Science 33:43-64.

FLINT, R.F. 1955. Pleistocene geology of eastern South Dakota. Geological Survey Professional Paper 262. U.S. Government Printing Office, Washington, DC.

Gaillard, J.-M., M. Festa-Bianchet, and N.G. Yoccoz. 1998. Population dynamics of large herbivores: variable recruitment with constant adult survival trends. Trends in Ecology and Evolution 13:58-63.

Gaillard, J.-M., M. Festa-Bianchet, N.G. Yoccoz, A. LOISON, AND C. ToÏGO. 2000. Temporal variation in fitness components and population dynamics of large herbivores. Annual Review of Ecology and Systematics 31:367-393.

GEIst, V. 1982. Adaptive behavioral strategies. Pages 219277 in J.W. Thomas and D.E. Toweill, editors, Elk of North America: ecology and management. Stackpole Books, PA.

Gerlach, T.P., and M.R. Vaughan. 1991. Mule deer fawn bed site selection on the Pinyon Canyon Maneuver Site, Colorado. Southwestern Naturalist 36:255-258.

Greer, K.R., and W.W. Hawkins Jr. 1967. Determining pregnancy in elk by rectal palpation. Journal of Wildlife Management 31:145-149.

Hamlin, K.L., D.F. PaC, C.A. Sime, R.M. Desimone, and G.L. Dusek. 2000. Evaluating the accuracy of ages obtained by two methods for montane ungulates. Journal of Wildlife Management 64:441-449.

Huegel, C.N., R.B. Dahlgren, and H.L. Gladfelter. 1986. Bedsite selection by white-tailed deer fawns in Iowa. Journal of Wildlife Management 50:474-480.

Lehman, C.P. 2015. Evaluation of elk movement, nutritional condition, pregnancy rates, and calf survival in the southern Black Hills of South Dakota. South Dakota Department of Game, Fish and Parks Division Report Number 2015-04, Pierre, SD.

Lehman, C.P., M.A. Rumble, C.T. Rota, B.J. Bird, D.T. Fogarty, AND J.J. Millspaugh. 2016. Elk resource selection at parturition sites in the Black Hills, South Dakota. Journal of Wildlife Management 80:465-478.
Lima, S.L., AND L.M. DiLl. 1990. Behavioral decisions made under the risk of predation: a review and prospectus. Canadian Journal of Zoology 68:619-640.

Linnell, J.D., R. Aanes, and R. Andersen. 1995. Who killed Bambi? The role of predation in the neonatal mortality of temperate ungulates. Wildlife Biology 1:209-233.

Linnell, J.D.C., P. Nijhuis, I. Teurlings, and R. AnderSEN. 1999. Selection of bed-sites by roe deer Capreolus capreolus fawns in a boreal forest landscape. Wildlife Biology 5:225-231.

Long, R.A., J.G. Kie, R.T. Bowyer, And M.A. Hurley. 2009. Resource selection and movements by female mule deer Odocoileus hemionus: effects of reproductive stage. Wildlife Biology 15:288-298.

Mao, J.S., M.S. Boyce, D.W. Smith, F.J. Singer, D.J. Vales, J.M. Vore, and E.H. Merrill. 2005. Habitat selection by elk before and after wolf reintroduction in Yellowstone National Park. Journal of Wildlife Management 69:1691-1707.

MEch, L.D. 1970. The wolf: ecology and behavior of an endangered species. Natural History Press, New York, NY.

Mich, P.M., L.L. Wolfe, T.M. Sirochman, M.A. Sirochman, T.R. Davis, W.R. Lance, and M.W. Miller. 2008. Evaluation of intramuscular butorphanol, azaperone, and medetomidine and nasal oxygen insufflation for the chemical immobilization of whitetailed deer, Odocoileus virginianus. Journal of Zoo and Wildlife Medicine 39:480-487.

MielKe, P.W., And K.J. Berry. 2001. Permutation methods: a discrete function approach. Springer-Verlag, New York, NY.

Mysterud, A., AND E. Østbye. 1999. Cover as a habitat element for temperate ungulates: effects on habitat selection and demography. Wildlife Society Bulletin 27:385-394.

Pitman, J.W., J.W. Cain III, S.G. Liley, W.R. Gould, N.T. Quintana, and W.B. Ballard. 2014. Post-parturition habitat selection by elk calves and adult female elk in New Mexico. Journal of Wildlife Management 78:1216-1227.

Poole, K.G., R. Serrouya, and K. Stuart-Smith. 2007. Moose calving strategies in interior montane ecosystems. Journal of Mammalogy 88:139-150.

Rearden, S.N., R.G. Anthony, and B.K. Johnson. 2011. Birth-site selection and predation risk of Rocky Mountain elk. Journal of Mammalogy 92:1118-1126.

Robel, R.J., J.N. Briggs, A.D. Dayton, and L.C. Hulbert. 1970. Relationships between visual obstruction measurements and weight of grassland vegetation. Journal of Range Management 23:295-297.

Roberts, B.A., And D.I. Rubenstein. 2014. Maternal tactics for mitigating neonate predation risk during the postpartum period in Thomson's gazelle. Behavior 151:1229-1248.

Shallow, J.R.T., M.A. Hurley, K.L. Monteith, and T. BOWYER. 2015. Cascading effects of habitat on maternal condition and life-history characteristics of neonatal mule deer. Journal of Mammalogy 96:194-205.

Sikes, R.S., W.L. Gannon, and the Animal Care and Use Committee of the American Society of Mammalogists. 2011. Guidelines of the American Society of Mammalogists for the use of wild animals in research. Journal of Mammalogy 92:235-253. 
Simmons, L. 1982. Photo series for quantifying forest residues in the Black Hills: ponderosa pine typespruce type. U.S. Forest Service, Rocky Mountain Region, Fort Collins, CO.

Singer, F.J., A. Harting, K.K. Symonds, And M.B. Coughenour. 1997. Density dependence, compensation, and environmental effects on elk calf mortality in Yellowstone National Park. Journal of Wildlife Management 61:12-25.

Smith, B.L., and S.H. Anderson. 1996. Patterns of neonatal mortality of elk in northwest Wyoming. Canadian Journal of Zoology 74:1229-1237.

Smith, J.B., T.W. Grovenburg, and J.A. Jenks. 2015. Parturition and bed site selection of bighorn sheep at local and landscape scales. Journal of Wildlife Management 79:393-401.

South Dakota Department of Game, Fish and Parks. 2015. Elk Management Plan for South Dakota.
Completion Report 2015-01. South Dakota Department of Game, Fish and Parks, Pierre, SD.

Thomas, J.W., H. Black Jr., R.J. Scherzinger, and R.J. Pedersen. 1979. Deer and elk. Pages 104-127 in J.W. Thomas, editor, Wildlife habitats in managed forests: the Blue Mountains of Oregon and Washington. Agricultural Handbook No. 553, U.S. Government Printing Office, Washington DC.

Vore, M.J., AND E.M. SChMidT. 2001. Movements of female elk during calving season in northwest Montana. Wildlife Society Bulletin 29:720-725.

Wallace, M.C., AND P.R. KRausman. 1990. Neonatal elk habitat in central Arizona. Pages 69-75 in R.D. Brown, editor, The biology of deer. Springer, New York, NY.

Received 11 December 2015 Accepted 26 April 2016 